Sazan Kryeziu

\title{
The Unsayable Mystery of the Holy: Hölderlin's Late Poetry
}

Keywords: the holy, Friedrich Hölderlin, Martin Heidegger, Ludwig Wittgenstein, language.

DOI: $10.4312 /$ ars.13.1.318-338

Heidegger's important and most engaging elucidations of Hölderlin's poetry provide abundant questions that are primarily suited to Heidegger's philosophy itself. His extrapolations on a certain number of Hölderlin's lines have frequently been dismissed, even by prominent philosophers like Theodor Adorno, who views Heidegger's method as "false", in that, "as method, it detaches itself from the matter at hand and infiltrates the aspect of Hölderlin's poetry that requires philosophy with philosophy from the outside" (Adorno, 1992, 128).

I will begin this paper by discussing the question of the mystery of the holy in Hölderlin's late poetry, focusing mainly on Heidegger's discourse on the matter. There seems no point in trying to summarize Heidegger's word by word analysis of Hölderlin's poems, therefore, in the subsequent text I will immediately get to the first remark, which will explain the characterization of Being as the holy, as I will attempt to show how consistent Heidegger's reading of Hölderlin's text is with Hölderlin himself. This will ultimately lead to my interpretation which takes as central Hölderlin's own conception of the holy as "the immediate" (Heidegger, 2000, 84). My thesis assumes that language is precisely what poetry cannot name. The holy is the immediate that cannot be said, but that is the principle of all saying. As an infinite resource, language is the presence of Being as the holy that remains a mystery - the mystery of the unsayable that manifests itself beyond language. Being as the holy bespeaks the poet in a saying to which the poet responds by articulating the address into words, or to put it into Heideggerian terms - the coming-to-presence of things in their being (i.e. exposing them in their truth) is made possible through the poetic word - but which nevertheless ends up in the disappearance of what it makes manifest. It becomes manifest, perhaps, as the revelation of the Word of God who says Itself to Itself in saying (addressing) Itself to us.

In order to draw my thesis near to the sphere of the rational, in the second part of the paper I offer an interpretation of Wittgenstein's thoughts on "the mystical", by 
confronting it with the nonrational moments which belong to the content of the idea of the holy explained in the first part. On my proposed interpretation, Wittgenstein's views on language as the unsayable or "inexpressible" are summed up in the following ideas:

1. What finds its reflection in language, language cannot represent.

2. What expresses itself in language, we cannot express by means of language.

3. What can be shown, cannot be said.

4. There are, indeed, things that cannot be put into words. They make themselves manifest. They are what is mystical. ${ }^{1}$

Under these headings, I will attempt to offer a "rational reconstruction" in the sense that I hope to restore to its rightful place the idea of poetic language as the mystery of the unsayable, and to bring it into the light, namely, to distinguish and analyse it as far as possible through the apophatic philosophical reflections of Heidegger and Wittgenstein.

Being receives many names in Hölderlin's poetry, yet the meaning remains the same. First it is called "nature" i.e. nature not in the ordinary sense of the word as that opposed to art, but in the sense of the Greek word physis, nature being the way whereby all things come to presence, that is, physis as "a rising into the open" - to use Heidegger's vocabulary. In this sense, nature is the poetic name for Hölderlin's Being. One of Hölderlin's late and last poems which was also a favourite of Heidegger's is called Autumn, and was composed "one year before Hölderlin's death" (Capobianco, 2014, 29). This is the poem in full:

Nature's gleaming is higher revealing,

Where with many joys the day draws to an end,

It is the year that completes itself in resplendence,

Where fruit come together with beaming radiance.

Earth's orb is thus adorned, and rarely clamours

Sound through the open field, the sun warms

The day of autumn mildly, the fields lie

As a great wide view, the breezes blow

Through boughs and branches, rustling gladly,

When then already to emptiness the fields give way.

The whole meaning of this bright image lives

As an image, golden splendour hovering all about. ${ }^{2}$

1 Wittgenstein, L., Tractatus: 4.121, 4.1212, 6.522.

2 As translated by Richard Capobianco; in: Capobianco, 2014, 28-29. 
The first line "Nature's gleaming is higher revealing" is the one the poem dons for the reader; it is indeed another expression of the ontological difference between Being and beings. Heidegger's commentaries, and of his scholar Capobianco (2014), on the line in question and the poem as a whole try to provide an explication "as faithfully as possible to the poem's intentions". But the philosophical language that Heidegger uses is also the language that Hölderlin tries to convey to us. Nature's gleaming is indeed a "higher kind of manifestation", that is to say, of divine essence (as Spirit). Nature as Spirit gives life to all beings present, it be-spirits all beings into their Being. As such, nature's gathering of itself in its unconcealment is to be seen both as an endless origin and as a perpetual presence of existence. This kind of presencing of existence as Spirit serves as mediation amongst beings. But this much Hölderlin's poem itself says. By drawing a comparison between "nature" and "landscape" Heidegger asserts that landscape "lets appear nature in an initial gleaming" (Capobianco, 2014, 30).

What makes "nature's gleaming" holy?

Nature safeguards and conserves beings (man and others alike) in the integrity of their Being. For Hölderlin nature is the holy because it is the "all-creative" and "allalive", and is "older than the ages and above the gods". The holy is that which comes before man, the gods, God or any divinity, in other words, it is that by which they, too, are. "The holy is not holy because it is divine; rather the divine is divine because in its way it is 'holy'... The holy is the essence of nature." (Heidegger, 2000, 82). As a "law" that lies beyond human law or God's or gods', it is that which makes possible the integrity of all beings into their Being. In this respect, the holy as the essence of nature ("the divine One") gathers together All, that is, the multiplicity of all beings (men, landscape, seasons, trees.) This very gleaming manifests itself as a "higher revealing" or appearing (= appearing in the sense of eidos, too, perhaps) hence a manifestation of the holy (the One), as the source of light by which All beings shine-forth and manifest themselves. In this sense, nature as "a golden splendour" imbues everything that is there, by "hovering all about". We should however note here that the view and rendering of "One is All" is not a new one; for Being and the One have been conjoined since Parmenides. Nevertheless, Heidegger insists that the One that he is speaking about has nothing to do with any metaphysical entity, and as he observes, "the gleaming of nature is not a state or condition (Zustand), but a happening (Geschehen)". This gleaming as a self-revealing aspect of Being constantly makes itself felt in the multitude of beings and events through its variously articulated forms of nature. But since this multitude of beings is ultimately nothing other than an unveiling or selfrevealing aspect of Being itself, one who approaches nature only through its variously articulated temporal forms would fail to perceive the unrevealed presence of All that passes from $\operatorname{god}(\mathrm{s})$ to man, without which nature as the holy would lose its essence, 
because "nature is Nature only after the naming it receives from the poet, since, if the speech that establishes comes from him, he is only answering the exigent call of the Sacred" (Blanchot, 1995, 119-120). Thus, the All is to be found in the poet's calling of the holy, because only through his song will the gods find their truth among the living. The poet's task is to say this unsayable poem, but he lacks the divine strength to name it. We should, however, note the difference between saying and naming. According to William S. Allen, the difference is that "while the holy unveils itself in the word it does not do so in a manner that would make it present as the saying of the word. This is because its essence is to be coming, so in becoming separated from its nonessence as what is present, poetic naming names what is as what is coming, that is, what is not present. Thus the essence of nature, the holy, unveils itself not by becoming apparent in the saying of its name but in unveiling itself as the inappearence of the word, its imminence" (Allen, 2007, 101). In this regard it might be said that, for Hölderlin, the holy is the All that is the concealed name of Being.

In the second stanza of Hölderlin's Pindaric hymn As on a Holiday (1800), the emergence of the holy is conceived as wonderfully "All-present", which embraces the poets:

So in favourable weather they stand

Whom no master alone, whom she, wonderfully

All-present, educates in a light embrace,

The powerful, divinely beautiful nature.

So when she seems to be sleeping at times of the year

Up in the heavens or among plants or the peoples,

The poets' faces also are mourning,

They seem to be alone, yet are always divining.

For divining too she herself is resting. ${ }^{3}$

Heidegger observes: "Only because there are those who divine, are there those who belong to nature and correspond to it. Those who correspond to the wonderfully all-present, to the powerful, divinely beautiful, are "the poets" (Heidegger, 2000, 78). Poetry is in essence a relation between gods and the people, in addition, the very essence of the poet is drawn into this omnipresent embrace of the holy, thus, only an authentic poet is able to speak of the gods (experience the holy) and name the divine. "Because this light embrace [of the Holy] educates the future poets, they, as the initiated ones, know the holy" (Heidegger, 2000, 85). As "[nature] seems to be sleeping at times" and "poets seem to be alone", they both share a common mourning. Why mourning? Heidegger explicates that "this mourning, however, is not merely an arbitrary darkness, but a divining rest. Night is the resting divination of the day" (Heidegger, 2000, 80).

3 As translated by Keith Hoeller; in: Heidegger, 2000, 69. 
But now day breaks! I awaited and saw it come,

And what I saw, may the holy be my word. ${ }^{4}$

I think that the contrast between the passing of the night's darkness and the coming of daybreak might not be understood merely in the sense of Heidegger's explication, namely as "the coming of the divining nature that has been to rest" or "the pure calling of what those poets who are always divining wait and long for" (Heidegger, 2000, 80), but rather that it may also refer to that particular realm of Being as the holy as it discloses itself to the poet at the stage when "according to firm law, as once begotten out of holy Chaos / Inspiration, the all-creative / Again feels herself anew." (stanza 3). The poet witnesses the holy Chaos, that is to say, he experiences the annihilation of all outward manifestations of nature. Yet Hölderlin does not seem to say that this state of inspiration (in the sense of divine madness) is a falling into an abyss where nothing could be discernible anymore, but rather that this abyss or darkness is also said to be bright, in that Being in itself is essentially luminous, illuminating itself as well as the poet's self. According to Heidegger, "the poem speaks of the poets and of the gift of the song only because the holy is the terror of universal shaking" (Heidegger, 2000, 94). But why must the final word of the poem return to the holy? What is the meaning of the holy in these two ambiguous lines of Hölderlin? For de Man, "it is not because he has seen Being that the poet is, therefore, capable of naming it; his word prays for the parousia, it does not establish it. It cannot establish it for as soon as the word is uttered, it destroys the immediate and discovers that instead of stating Being, it can only state mediation." (de Man, 1983, 258-259) Thus, de Man rejects Heidegger's reading of Hölderlin, arguing that Heidegger's interpretation of the former's poetry raises a question as to the entire possibility of naming being. For the theorist of Deconstruction, no event that is present in Hölderlin's poetry is about the coming-into-being of the holy, but instead it is about the rift between language and being, or the articulation of the difference and opposition between the immediate being and a mediating language, that is to say, it is about the difference between the absolute Being and the languaged being.

We might say that the holy is the trace of the unsayable mystery of the poet's speech that is made manifest in his words, yet cannot be said, except through this trace that it leaves behind in the language that cannot say it. The poet yearns to say it, but cannot, since the very calling of it would extinguish it. However, the holy as the unsayable mystery of speech is the very source of presence by which gods and men are present to each other and to There-being, hence There-being functions as the immediate mediation between them. But the holy is not yet the poet's word, for the poet still needs the Omnipresence to exist and the Omnipresence needs his mediation in order to be able to divine his destiny: 


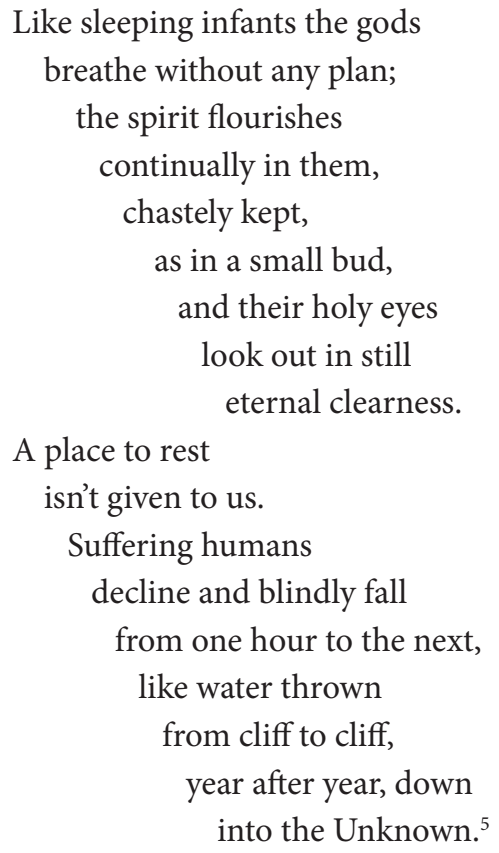

(Hyperion's Song of Destiny, stanzas 2 and 3)

The holy here is the trace of the departed gods. The poet must take his stand and speak of the gods, for his task as a mediator is to connect the near to the far. Gods themselves determine what the poet is to divine, therefore, the poet must be responsive or attune himself wherever the holy discloses itself to him. Such attuning will be possible if the poet expresses a word, that only the holy, preserved within him, may utter. By preserving the holy, he becomes a seer who foresees the time of the thing created $(\pi \circ \imath \mu \alpha)$, of which he is the creator. "It is because", as Blanchot observes, "the poem is previous to the poet, and exactly this ahnen is the way for the poet to feel that he exists before himself and, free as he may be, as free as the swallow, in the dependence on this very freedom, his response may be free but it is a response to this freedom" (Blanchot, 1995, 118-119). Yet, to the important question as to whether the holy is embodied in the poet's word, or whether the word itself, in the form of Hölderlin's poem and this specific performative utterance, generates the holy, Angela Esterhammer remarks that "the speech act engages a reciprocal relationship between speaking subject and articulated object, between I and Other, and between language and reality, and engages as well the questions raised and left unanswered by Romantic theorists about the relative priority of consciousness and language" (Esterhammer, 2000, 189). According to Esterhammer, Hölderlin's language "is rooted in a phenomenological 
understanding of the way language constructs relationships between mind and world in the first place" (ibid., 191). Unlike Esterhammer, we would rather contend that Hölderlin's poetic language establishes the real by unfolding a spiritual order behind the material world.

For Hölderlin, the holy is the immediate. The immediate establishes a mutual relationship between beings, hence it serves as mediation between them. Inspired from an early fragment of Pindar, Hölderlin writes:

The immediate, strictly speaking, is as impossible for the mortals as for the immortals; the god must distinguish different worlds, in accordance with his nature, because heavenly goodness, for its own sake, must be holy, pure. Man, as the knowing one, must also distinguish different worlds, because knowledge is only possible through opposition. For this reason, the immediate, strictly speaking, is as impossible for the mortals as for the immortals. Strict mediatedness, however, is the law. (Heidegger, 2000, 84)

The holy as the immediate, however, is not directly approachable to the poet, for he cannot name it in itself, rather it discloses itself to him mediately i.e. in and through beings which it renders present, for which it is the mediation. Man himself dwells in the vicinity of the holy, the same manner as the gods do. Mediation is first to be seen as an "openness of the open which comes into a connection with what we call a "world" (Heidegger, 2000, 86). For Heidegger, "the open itself is the immediate" (ibid., 83). The openness is the dwelling place of the poet where he welcomes the gods in his poetry. He is thrown away "from cliff to cliff" in mediation, between the gods and his people. But to unveil the mystery of language is to unveil the origin of Being. Instead, the poet's task as "half-god" or a privileged mortal is to respond to Being and recognize the holy as mediated through beings, for he must accept and respect the inaccessibility of Being in itself. As Heidegger puts it:

The immediate is itself never something mediate; on the other hand, the immediate, strictly speaking, is the mediation, that is, the mediatedness of the mediated, because it renders the mediated possible in its essence. (Heidegger, 2000, 84)

Mediation comes from what is superior or above the poet, that is, closer to some source of light of the holy, but not itself the holy, since it is only a being. Through the source of light the poet may be enlightened by the holy, for the holy cannot be found by itself, but in the beings that it illuminates. The poet is aware of the fall into the Unknown, for this was the destiny as determined by the gods, and whether the coming of gods will be the gods of ancient Greece or the Christian God is determined from and within the realm of Being. In Heidegger's interpretation, "homecoming" is to be understood as 
"the return to the nearness to the origin" (Heidegger, 2000, 42). The god that Hölderlin speaks of, is mysterious, that is, he is the unknown. God appears to men as a mysterious being. Yet the god that the poet refers to is not the religious God of the Christian faith, for Hölderlin is not a religious poet, but "a poet of Being" as Heidegger puts it. ${ }^{6}$

In my view, the very drive of man to reach and grasp the concrete coordinates of individual existence (as is the case with Hölderlin's poetry and thinking), is to be understood as a religious drive and here the term religious is not necessarily used according to the doctrines of monotheistic religions, but in a spiritual sense of the word). This is particularly the case with Hölderlin's much interpreted line "poetically man dwells on this earth" for which Heidegger dedicated a whole essay. Following Jung's assertion that "man is naturally religious" , I think that Hölderlin's line may also be understood in the same light, that is to say, man is supposed to dwell poetically on this earth in the sense of a syncretism between conscious and unconscious dimensions. In this aspect, the reality of Dasein, in my view, is mystified, i.e., it is not (merely) a thingly existence, but fused with mysterious dimensions (God, gods, sky, plants). Encountered with the universal and transcendental phenomena, there is grown up in man a feeling of affinity with all things that surround and fill him: animals, plants, sky, gods, and the eternal in him.

For Hölderlin, Christ is a divinely begotten hero. (Dilthey, 1985, 383) Gadamer, on the other hand, observes that for Hölderlin, Christ is of different nature than presence, because he is not only of his life on earth compared to the Greek gods, whose activity is just presence:

The poets, then, must be of this world, because they can sing only of the present in which they are imprisoned. It is part and parcel of Hölderlin's present that Christ is not accessible to poetic form. The Greek gods are the present time of legend that becomes reinterpreted for the poet in the light of "ever-present" nature. Christ, on the other hand, is he who lives in faith and whose worship is “in the spirit”. For Christ still lives. (Gadamer, 1994, 79)

6 Heidegger excludes God from Being, however, if according to Heidegger (in the latter phase of his career), Being is to be understood as Lichtung (open clearing) into which man transcends himself, and his concept of Wissen (knowing) as standing in the truth, and where truth (aletheia) is the unconcealment of the existent, then these ideas immediately bring back to our mind the remarkably close understanding of the mystics' idea of Reality and Knowing (God) as Presence and Light (Suhrawardi's metaphysics, for instance). In the same vein as Heidegger, Jean-Paul Sartre's thinking seems more persistently logical and scholastic with regard to the spiritual realization of the Lichtung of Being. For Sartre, the world of Being is separated between subject and object (i.e. between the realm of human consciousness and the realm of things) which can never be fused.

7 This assertion lies at the core of Jung's philosophy. For a detailed understanding of this philosophy please read C.G. Jung's The Function of Religious Symbols and On Spiritualistic Phenomena; in: The Symbolic Life: Miscellaneous Writings: The Collected Works of C.G. Jung, (ed. McGuire, W.), Princeton, NJ, 1997. 
In the poem that bears the title The Poet's Vocation, Hölderlin writes:

fearless/man stands, and lonely before God

no weapon he needs

Till God's being not there helps him. ${ }^{8}$

The poet's task is to remind his people not to give homage to false gods, but to await the signs of the approaching of a future god, as a salvation for his people. It seems as if Hölderlin foresaw the godless world of the modern age characterized by the technological worldview of Western civilization in which the absence of any god holds sway. Or to put it in the words of John R. Williams, "Hölderlin was one of the first to recognize this desacralization of the world, and Heidegger feels that his poetry provides an excellent description of this aspect of modern civilization (which is as valid today as during Hölderlin's own lifetime)" (Williams, 1977, 129). We are living in an epoch which lies between the absence of the past gods and the absence of a new one, therefore the poet, as long as this absence lasts, must teach his people how to live in the vicinity of "the essence of things", or dwell poetically on this earth. In his essay What are Poets for?, Heidegger remarks:

The default of God means that no god any longer gathers men and things unto himself, visibly and unequivocally, and by such gathering disposes the world's history and man's sojourn in it. The default of God forebodes something even grimmer, however. Not only have the gods and the god fled, but the divine radiance has become extinguished in the world's history. The time of the world's night is the destitute time, because it becomes ever more destitute. It has already grown so destitute, it can no longer discern the default of God as a default. (Heidegger, 2001, 89)

This is what Friedrich Nietzsche would call "the death of God", insofar as we are living in an epoch that has forgotten Being. For the philosopher of nihilism, the death of God marks the death of metaphysics, or rather the forgetfulness of Being as "unawareness of the mystery" or a "mittence of Being" (Richardson, 2003, 436) At the beginning of the $20^{\text {th }}$ century, Rilke, the poet, was aware that Nietzsche's doctrine must change, therefore in an attempt to overcome nihilism he proposes salvation at the time of the absence of god, by returning instead to the authentic use of language, which lies in the inner space of the human heart. He conceives of Being as "the Open", a gravitational force that boundlessly draws all beings unto itself as well as acting towards one another, understood as universal Will. Whereas for Hölderlin, the poet is given the understanding of Being as a necessity for the encounter with gods in the presence of the holy. By living in the presence of the holy, therefore letting the truth appear, the poet will show his people how to $d w e l l$ on this earth. The holy is revealed

Translated by Christopher Middleton; in: Hölderlin, 1990, 157. 
to him in the form of verbal expression, and it is by reason of this very essence that Being passes into a word. Yet, the final words of Hölderlin's hymn As on a Holiday read:

I approached to see the Heavenly,

And they themselves cast me down, deep down

Below the living, into the dark cast down

The false priest that I am, to sing,

For those who have ears to hear, the warning song.

There $^{9}$

This last stanza of Hölderlin's hymn does not appear in every edition of his collected poetry nor does it appear in Heidegger's Elucidations (who surprisingly decides to leave the lines out). However, it can be found in the original manuscript of Hölderlin which shows that the poet crossed out a number of verses and words. The reason why I have chosen these omitted but very important lines is that they express the poet's recognition of the absence of an authentic language in the epiphany of his suffering self-negation. The poet can hear the voice of gods, but is banished to live on earth and sing to his fellow men in a real language. This authentic language is silence. The poet realizes that he can enter into an appropriate relationship with the gods only through a grounding-attunement, which dwells in silence, after realizing that his poetic language not only revealed, but concealed the being of things. Yet the poet is "into the dark", which I think, refers to the unreality of the world that he has been experiencing. In this aspect, the holy functions as an impenetrable dark veil obstructing the poet's sight to see or approach the self-revealing "truth of Being." Thus, it is through silence as the unsayable of the holy that humanity can reach into the depths of God. To be "modern" or "post-modern", in my view, is to abandon the God-intimacy as the root of the experience of the holy through silence, and instead setting out to approach the essence of things merely through language or speech. In this respect, I daresay that even philosophy has become an "irresponsible rhetoric" (Girard, 2001, 175), in the sense that philosophers, each in his own way, attempt to assume truth through the use of their vocabulary. Yet, how can the holy, which is unsayable, become speech? Blanchot insists that it can, insofar as "silence is marked by the same contradiction and the same tearing apart as language: if it is a way to approach the unapproachable, to belong to what is not said, it is "sacred" only insofar as it makes communication of the incommunicable possible and arrives at language" (Blanchot, 1995, 129).

The unsayable is a prerequisite for dwelling in the vicinity of the holy, and must not be identified with the holy itself. The unsayable is to be understood as a mode of augmented receptivity to the word, but not constitutive of it. There must be silence for this word to make itself heard, or in other words, it is through silence that we can 
clearly hear and understand the spoken word. It is important to further substantiate the interrelationship between the unsayable beyond language and ordinary language in terms of Meister Eckhart's ontological distinction between Beyond-Being and Being: "God is a word, an unspoken word. . . Where God is, He utters this Word-where He is not, He does not speak. God is spoken and unspoken" (Kazemi, 2006, 135). Speaking in accordance with Eckhart's distinction, one could say that unsayability may be found in the omnipresence of God's no-thingness, or as Kazemi observes: "At the plane of Being - 'where God is' - the Word is spoken, whilst on the plane of Beyond-Being 'where He is not' - there is silence, no-thing. That does not mean 'nothing' in the sense of the negation of Being, but rather nothing as That which surpasses and comprises all 'things' as well as Being itself, is clear from the fact that Eckhart says: 'God is spoken and unspoken." (ibid., 135) If we are thus to identify the unspoken God with the unsayable beyond language, it might be said that the unsayable "transcends both linguistic expression and the very particularity that language necessarily entails," (Katz, 1992,3 ) for language is merely a system of signs where signs cannot speak themselves, but can only speak through other signs. ${ }^{10}$

Still more puzzling is the question of whether what can be experienced cannot be said in words. Alfred Schutz notes that "for 2,000 years, the problem of philosophy has been not 'How do I know the things of the outer world?' but 'What is the relation of the concept to that which I have designated with and also apperceived in a word?' " (Schutz, 2013, 127) Our question would be: does the world of words exist only outside the world, or is our cognition of it possible only through the world of words? And will one's original experience be altered if one names the experience linguistically? Does the mystics' view that the unsayable is beyond language, make it nonlinguistic? Or is the unsayable unrelated to language (Blanchot)? Or is it inseparable from language (Derrida)? Or is it the essence of language ("das Wesen der Sprache") itself, as Heidegger maintains? Paradoxically enough, it might be said that the unsayable is

10 Unlike most modern theorists and philosophers who claim that language determines all of reality, Ibn Arabi, the $13^{\text {th }}$ century Islamic mystic, claims that the origin of language cannot be found in anything other than God. The self and indeed all of reality, according to Ibn Arabi, is "nothing but a word articulated by the Essence, and the Essence remains always and forever beyond any articulation. So also, every language, whether meta-, cosmic, human, or infrahuman, is an articulation of Unarticulated Wujū d" (=Being). I think it would be worthy of attention in the context of our argument, to present here Ibn Arabi's understanding of language, as explained by his scholar William C. Chittick: "On the formal level, language is first an articulation of the breath. The breath (nafas) is the life force, and, in the human case, the life force is the self (nafs). Language articulates the contents of the self in a barzakh, an isthmus- i.e., the breath-that is neither immaterial like the self, nor material like the external world. We know the barzakh is there because we experience its articulation, not least through enunciating and hearing spoken words. Language is intelligible, because the self is intelligent, and it is sensory, because it is perceived by sensation. Hence it is a world of imagination, a barzakh between awareness and embodiment, meaning and form, reason and sensation, self and other. It is an image of the self and of the world outside the self. It is neither here nor there, neither this nor that. It clarifies and obscures, reveals and veils." (Chittick, 1997, xxxii-xxxiii) 
made possible only through language, as in the lines of Rumi: "When you say, 'words are of no account', you negate your own assertion through your words. If words are of no account, why do we hear you say that words are of no account? After all, you are saying this in words" (Katz, 1992, 3). In order to make some sense on these questions, I propose that in this second part of the paper we return to Wittgenstein's Tractatus, and specifically to his views on the mystical as the "unsayable" or "inexpressible", according to the ideas presented at the beginning of this paper.

Ludwig Wittgenstein actually claims in the Tractatus that "What finds its reflection in language, language cannot represent. What expresses itself in language, we cannot express by means of language" (Wittgenstein, 1974, $\$ 4.121$ ). To achieve this representation we would have to place ourselves "somewhere outside logic, that is to say outside the world" ( $\$ 4.12$ ). And if this logical form is mirrored in propositions, what could be identified in the unsayable (as the outside of the world), that the reflection is of the world? It seems that nothing that is sayable could identify what is unsayable as identically mirrored in language. The philosopher of logic observes: "Language disguises thought. So much so, that from the outward form of the clothing it is impossible to infer the form of the thought beneath it, because the outward form of the clothing is not designed to reveal the form of the body, but for entirely different purposes" ( $\$ 4.002)$. On this view language disguises its essential structure. According to Wittgenstein, a proposition can only say how a thing is, and not what it is. Further, "to view the world sub specie aeterni is to view it as a Whole - a limited whole." ( $\$$ 6.45). This world as "a limited whole" (begrenztes Ganzes), is what Wittgenstein calls the "mystical". The infinite of language encounters a limit and transpires against the unsayable checked by the silence or speechlessness of nature. Yet in the context of our argument, the following question must be posed: Can the logical limits of language be transcended by poetic language? William Franke succinctly observes:

It seems that poetry excels only in the expression of inexpressibility and that this alone, paradoxically, becomes the mode in which the sense of alterity and singularity can be communicated. Not by being communicated but rather by being marked as evading all linguistic formulations, the inexpressible is made at least to show up in poetry. As in Wittgenstein's dictum, the inexpressible "shows itself, it is the mystical." (Franke, 2014, 85)

There are, indeed, says Wittgenstein, things that we cannot put into words $(\$$ 6.522). This inexpressible as the mystical shows itself or makes itself manifest, yet might this way of showing or manifesting be something that cannot be said, or in other 
words, is there a showing of what cannot be said? According to Franke, the linguistic trace of what cannot be said must precede-and in fact constitute-any presencing or evidencing of the unsayable, which is, to this extent, intrinsically linguistic, that is, an effect of language (Franke, 2014, 153). Taking his cue from Jacques Derrida's discussions of the trace, Franke maintains that "the trace is all that ever becomes real and effectual of the presence, which is never manifest as presence itself and as such but always only as some recognizable, specifiable trait, an instituted trace, which refers to what it is not and cannot re-present but can only mark as vanished, absent, inaccessible" (ibid., 153). The unsayable is thus "a trace that cannot be traced back to any origin" (ibid., 153).

We cannot trace the unsayable back to any origin, because we cannot put ourselves "outside of the world" (outside logic), for we would thus pass into the realm of silence. In these terms, "what can be shown, cannot be said", claims Wittgenstein, in the sense that language displays the reality that makes itself manifest but cannot be said, for language is just its in-the-world structure. I think that Wittgenstein sees a unity between two kinds of showing, that is, the showing of what lies outside the world and the showing that lies in-the-world. These two worlds are not separate, but bounded by a mutual structure of consciousness that is transcendental, which manifests itself both in the realm of logic and outside logic. Language and mind (logic) are the limits of the world which are separated by the transcending experience of the mystical. Russell Nieli remarks:

One cannot say what does not exist in the world, because what does not exist in the world is the out-of-the-world mystic union, and for expressing this experience, the in-the-world structure of language and logic is not appropriate. Similarly, the out-of-the-world experience cannot be construed in thought, because "thought" (Gedanke), in the technical sense of the Tractatus, is closely tied to picture-propositions $(3.01,3.1)$ i.e., to what can be said in language. (Nieli, 1987, 119-120)

In the mystical realm of experience there occurs a disembodiment of the self, for as Wittgenstein puts it: "the philosophical self is not the human being, not the human body, or the human soul, with which psychology deals, but rather the metaphysical subject, the limit of the world - not a part of it" (Wittgenstein, 1974, \$ 5.641). The disembodied self is therefore represented as the reduction of the metaphysical $I$ from its body (the denial of the reality of the ego) to a point from which it views the whole world. In other words, only in a mystical "flight" does a "world" come into being. Likewise, it might be said that only insofar as the poet destroys himself and the language he has created will the "world" come into being, or in other words, only at the limit of this negation might the unsayable take place. 
While for Wittgenstein the limits of the language are the limits of the world, for Heidegger language is the house of Being and in this house human beings dwell. He does not maintain, as Wittgenstein tells us, that beyond the philosophical language lies the "mystical", but proposes instead that the propositions of "reality" and "consciousness" must be brought together. Heidegger attempts to create a new transformed language, by demanding that grammar be freed from logic:

The Greeks had no word for "language"; they understood this phenomenon "in the first instance" as discourse. But because the logos came into their philosophical ken primarily as assertion, this was the kind of logos which they took as their clue for working out the basic structures of the forms of discourse and its components. Grammar sought its foundations in the "logic" of this logos. But this logic was based upon the ontology of the present-athand. (Heidegger, 1962, 209)

Yet for Heidegger, poetry is opposed to inauthentic discourse. Poetry (poiesis), according to him, is not a particular part of language; language originates in poetry. Poetry, he maintains, names being and the essence of all things; it is poetry which makes language possible, in the first place. In this sense, "the essence of language itself is to be understood through the essence of poetry". However, Heidegger's suggestion that we should seek that essence in poetry, as Karsten Harries remarks, "is no more convincing than Wittgenstein's decision to accept our language as a ground beyond challenge. Logic, ordinary language, and poetry must not be understood as three stages, where each successive stage is taken to be more fundamental than the one which preceded it, but as three dimensions which have to be seen together" (Harries, 1968, 291). It is also important to direct our attention here, however briefly, to Wittgenstein's paralleling of ethics with aesthetics: "Ethics and aesthetics are one and the same" (Wittgenstein, 1974, $\$ 6.421$ ). What is the relation binding them, given the fact that they are two different domains? According to B. R. Tilghman, "they are parallel in that both belong to the domain of the unsayable; just as there are no ethical propositions, so there are no propositions stating aesthetic judgements. Both values can only be shown. Both involve a way of looking at things that is contemplative" (Tilghman, 1991, 64). In addition to this parallel, ethics and aesthetics, in Tilghman's words, "are intimately related in that art is one of the most important ways in which ethical value can be shown and a solution to the problem of life made manifest" (ibid.: 65). This seemingly plausible idea, however, raises a number of dilemmas, for my question would be: what does professor Tilghman mean by ethics, if he does not speak about the ethical act, but refers to the ethical only in light of the individual quest for spiritual balance?

Wittgenstein's identification of "the mystical" with that which cannot be put into words is closer to Eckhart's mysticism than to Heidegger's thought, for Heidegger's 
thought is linguistic rather than mystical. Whereas for Meister Eckhart silence replaces language, for Heidegger silence is the condition and also an attribute of authentic language, but only insofar as it is a break off or cessation within language, as in the lines of Stefan George's poem The Word: "So I renounced and sadly see: Where word breaks off no thing may be" (Heidegger, 1971, 73). The thing itself comes into being or comes to "be" only through language, and where there is no word, there is no thing either. As Heidegger remarks in his explication of the poem: "No thing is where the word is lacking. 'Thing' is here understood in the traditional broad sense, as meaning anything that in any way is. In this sense even a god is a thing. Only where the word for the thing has been found is the thing a thing. Only thus is it. Accordingly we must stress as follows: no thing is where the word, that is, the name is lacking" (Heidegger, 1971, 61-62). But once the poet experiences the limitation of language, he writes a poem instead, and does not lapse into silence. Why? Heidegger answers: "because this renunciation is a genuine renunciation, not just a rejection of saying, not a mere lapse into silence. As self-denial, renunciation remains Saying. It thus preserves the relation to the word" (Heidegger, 1971, 147). The difference between what is sayable and what is "unsayable in what is said" is rift (Riss). As Bernasconi explains:

Rift is the withdrawal, the withholding, the unspoken that accompanies all language and resounds in das Geliut der Stille. The recognition-in remembrance-of the history of Being does not mark the withdrawal of Being's withdrawal. It means rather that the silence is to be heard as silence and that the silence comes to permeate all speaking. The rift would thereby be maintained as a rift between the "inside" and "outside" of metaphysics or, better, between the first and another beginning (Bernasconi, 1985, 63).

Wittgenstein, on the other hand, is more restrained than Heidegger in this respect. Wittgenstein attempts to draw a limit to the expression of thought in language. Beyond this limit, there is nothing but silence. For Wittgenstein, silence is the only realm for the revelation of the mystical as the unsayable, which shows itself at the point or limit where language cannot reach. This realm where language cannot reach belongs to the sphere of ethics. To reach this necessary aspect of the world in which the ethical act resides, the metaphysical I, or the self, must transcend the specifics of rendering this world only by means of speech, babbling, and theorizing. It is for this reason, I think, that Wittgenstein ends his Tractatus in silence: "What we cannot speak about we must pass over in silence" (Wittgenstein, 1974, \$7). According to Dieter Mersch, "the mystical represents the place where every definition of the question of 'what' or 'how' ceases and only the pure presence in relation to absence manifests itself. That means: the world, as the self-revealing entity, 'is' only in the event"11 (Mersch, 2009, 30). But the

11 Mersch further explains that 'the expression 'event' or 'happening' (Ereignis) implies that the distinction between what can be said and not said is not accessible: it is not a constructive effect of 
mystical is not just the world, or being, or existence. The limits of being are non-being, nothingness, emptiness or the void, which are key concepts in mystical poetry as well. And if being as self-revealing entity originates in an event, it might be argued that the event discloses the emptiness (void) or nothingness of the place whence the being as truth originates. This is what Hölderlin told us:

[Gods] themselves cast me down ... to sing

For those who have ears to hear, the warning song.

There $^{12}$

The poet sings his song by naming the holy as there, there as the very being of the place as void (i.e. silence) as the limit to being (i.e. language). Poetry as the essence of all things, goes beyond words and concepts and excels precisely in the expression of the inexpressible, becoming thus the only realm in which the sense of singularity and otherness can be expressed. The inexpressible makes itself manifest in poetry, not by being expressed or articulated, but rather by avoiding linguistic formulations. The poet speaks, yet does not speak, and what is shown by him, is left unexpressed. But if gods ask him to speak to his audience through language, how is it possible for the audience or reader to hear and understand the poet? The idea of the audience in this aspect might be paralleled to Heidegger's conception of keeping silent as another essential possibility of discourse (Heidegger, 1962, 165). Keeping silent at hearing the poet's word, the audience "can develop an understanding", and actually can do so more authentically than the person who is never short of words (ibid.: 165). As Heidegger observes:

Keeping silent authentically is possible only in genuine discoursing. To be able to keep silent, Dasein must have something to say - that is, it must have at its disposal an authentic and rich disclosedness of itself. In that case one's reticence [Verschwiegenheit] makes something manifest, and does away with "idle talk" ["Gerede"]. As a mode of discoursing, reticence Articulates the intelligibility of Dasein in so primordial a manner that it gives rise to a potentiality-for-hearing which is genuine, and to a Being-with-one-another which is transparent. (Heidegger, 1962, 165)

Let us summarize. We began this paper, following some passages of Hölderlin's late poetry, with a simple identification of Being as nature and as the holy. Thus we continued to analyse Hölderlin's idea of the holy, principally according to the apophatic philosophical views of Heidegger and Wittgenstein, and attempted to

a discourse: it happens. It is therefore also not, as Derrida and J. Butler meanwhile seem to infer, marked arbitrarily and, by that, not transferable." Mersch, D., There are, indeed, things that cannot be put into words; in: In Search of Meaning: Ludwig Wittgenstein on Ethics, Mysticism and Religion (ed. Arnswald, U.), Karlsruhe 2009, p. 44.

See: Hölderlin, 1990, 197. 
make an analogy between Hölderlin's idea of the holy and Wittgenstein's conception of the mystical. Following Heidegger's thought, we have observed that the essence of poetizing is to be understood through the essence of language. In the second part we juxtaposed Heidegger's views with Wittgenstein's and found out that to trace the mystery of what cannot be said, back to an origin, means placing ourselves outside of the world (outside logic), passing thus into the realm of silence. We have found several passages that supported this interpretation. For Wittgenstein, it is through silence that the revelation of the mystical as the unsayable is made possible, "the mystical" which makes itself manifest at the point where language cannot reach. But we must clarify here that the showing of mystical-beyond or the holy and the showing of language and the world cannot be seen as two types of showing, but rather as bounded in a unity that originate in the transcendental. For Heidegger, on the other hand, silence permeates all speaking and the difference between what is unsaid and what is "unsaid in what is said" is rift. The manifestation of the rift according to Heidegger takes place in the withdrawal of being as the unsayable that accompanies all language and resonates in "the peal of stillness" (das Geliiut der Stille). To quote Meister Eckhart:

First we will take the words: "In the midst of silence there was spoken within me a secret word" [...] Yet in that ground [of the soul] is the silent "middle": here nothing but rest and celebration for this birth, this act, that God the Father may speak His word there, for this part is by nature receptive to nothing save only the divine essence, without mediation. (Schalow, 2001, 61)

We may sum up what we have found by saying that in Hölderlin's poetizing the holy is used to describe the immediate that cannot be said, but that is the principle of all saying. The holy is thus both the immediate and the mediation. The holy bestows the originary word upon the poet who is able to speak by listening to the sounds of silence. Struck by the holy, the poet hears the withholding of language in a new, transformed way. Hölderlin writes:

Often we must keep silence; holy names are lacking

Hearts beat and yet does speech hold back? ${ }^{13}$

It is precisely in the silence coming from the absence of the holy names that words from a prior grant of language begin to echo from afar. If phenomenology is the seeing of what is concealed, then, perhaps, the hearing of the peal of silence might also be given the same name.

13 Hölderlin's poem Heimkunft /An die Verwandten (stanza 6): "Schweigen müssen wir oft; es fehlen heilige Nahmen / Herzen schlagen und doch bleibet die Rede zurük?” (translated by Keith Hoeller; in: Heidegger, 2000, 30). 


\section{References}

Adorno, T., Notes to Literature, Vol. 2, New York 1992.

Allen, W. S., Ellipsis of Poetry and the Experience of Language after Heidegger, Hölderlin, and Blanchot, Albany 2007.

Bernasconi, R., The Question of Language in Heidegger's History of Being, Atlantic Highlands (NJ) 1985.

Blanchot, M., The Work of Fire, Stanford (CA) 1995.

Capobianco, R., Heidegger's Way of Being, Toronto 2014.

Chittick, W. C., The Self-Disclosure of God: Principles of Ibn-Al'Arabi's Cosmology, Albany (NY) 1997.

de Man, P., Blindness and Insight: Essays in the Rhetoric of Contemporary Criticism (revised $2^{\text {nd }}$ edition), London 1983.

Dilthey, W., Poetry and Experience, Vol. V, Princeton (NJ) 1985.

Esterhammer, A., The Romantic Performative: Language and Action in British and German Romanticism, Stanford 2000.

Franke, W., A Philosophy of the Unsayable, Notre Dame (IN) 2014.

Gadamer, H. G., Literature and Philosophy in Dialogue, Albany (NY) 1994.

Girard, R., I see Satan fall like Lightning, New York 2001.

Harries, K., Wittgenstein and Heidegger: The Relationship of the Philosopher to Language, in: The Journal of Value Inquiry 2, 1968, pp. 281-291.

Heidegger, M., Being and Time, (trans. John Macquarrie, Edward Robinson), Oxford 1962.

Heidegger, M., Elucidations of Hölderlin's Poetry, (trans. Keith Hoeller), New York 2000.

Heidegger, M., On the Way to Language, (trans. Peter D. Hertz), New York, Toronto 1971.

Heidegger, M., Poetry, Language, Thought, (trans. Albert Hofstadter), New York 1971.

Hölderlin, F., Hyperion and Selected Poems (ed. Santner, E. L.), New York 1990.

Hölderlin, F., Poems of Friedrich Hölderlin, (trans. James Mitchell), San Francisco 2007.

Jung, C. G., The Symbolic Life: Miscellaneous Writings: Collected Works of C. G. Jung (ed. McGuire, W.), Princeton (NJ) 1997.

Katz, S. T., Mysticism and Language, Oxford 1992.

Mersch, D., There are, indeed, things that cannot be put into words, in: In Search of Meaning: Ludwig Wittgenstein on Ethics, Mysticism and Religion (ed. Arnswald, U.), Karlsruhe 2009, pp. 25-50. 
Nieli, R., Wittgenstein: From Mysticism to Ordinary Language, Albany 1987.

Richardson, W. J., Heidegger: Through Phenomenology to Thought ( th $^{\text {th }}$ edition), New York 2003.

Schalow, F., Heidegger and the Quest for the Sacred: From Thought to the Sanctuary of Faith, Dordrecht 2001.

Schutz, A., Literary Reality and Relationships (Collected Papers, VI), Dordrecht 2013.

Shah-Kazemi, R., Paths to Transcendence according to Shankara, Ibn Arabi, and Meister Eckhart, Bloomington (IN) 2006.

Tilghman, B. R., Wittgenstein, Ethics and Aesthetics: The View from Eternity, Hong Kong 1991.

Williams, J. R., Martin Heidegger's Philosophy of Religion, Waterloo, Ontario 1977.

Wittgenstein, L., Tractatus Logico-Philosophicus, London 1974. 


\section{Sazan Kryeziu}

\section{Neizrekljiva skrivnost svetega: Hölderlinova pozna poezija}

Ključne besede: sveto, Friedrich Hölderlin, Martin Heidegger, Ludwig Wittgenstein, jezik

V Hölderlinovi poeziji je bit označena $\mathrm{z}$ več izrazi; ta razprava se osredinja na bit kot sveto. Bit kot sveto nagovarja pesnika v sporočilu, na katero se ta odzove $\mathrm{z}$ besedilom. V soglasju s Heideggerjevo mislijo, da je poezija (poiesis) bistvo jezika in vseh umetnosti, in ob soočenju $\mathrm{z}$ Wittgensteinovimi pogledi na jezik bomo poskušali pokazati, da slediti skrivnosti jezika do njegovega izvira pomeni postaviti se ven iz sveta, namreč, prestaviti se v območje tišine. Ob vzporejanju Hölderlinove ideje svetega kot tistega neposrednega in Wittgensteinovega pojma mističnega se razkrije, da je jezik natanko to, česar poezija ne more imenovati. 
Sazan Kryeziu

\section{The Unsayable Mystery of the Holy: Hölderlin's Late Poetry}

Keywords: the holy, Friedrich Hölderlin, Martin Heidegger, Ludwig Wittgenstein, language

Being is given many designations in Hölderlin's poetry, but we will focus on the question of Being as the holy. Being as the holy bespeaks the poet in a message to which he responds by articulating the address in words. Following Heidegger's thought that poetry (poiesis) is the essence of language and of all arts, and juxtaposing it with Wittgenstein's view of language, we will find out that to trace the mystery of language back to its origin means placing ourselves outside of the world, passing thus into the realm of silence. Drawing an analogy between Hölderlin's idea of the holy as the immediate and Wittgenstein's conception of the mystical, my thesis assumes that language is precisely what poetry cannot name. 